\title{
Seed Productivity of Various Alfalfa Varieties for the Foothill Zone of the North Caucasus
}

\author{
Nino Nodarovna Doguzova \\ Federal State Budgetary Institution of Science Federal Scientific Center "Vladikavkaz Scientific Center of the Russian Academy of Sciences", \\ Vladikavkaz, Russia
}

Email address:

doguzovanino@yandex.ru

\section{To cite this article:}

Nino Nodarovna Doguzova. Seed Productivity of Various Alfalfa Varieties for the Foothill Zone of the North Caucasus. International Journal of Applied Agricultural Sciences. Vol. 7, No. 2, 2021, pp. 98-101. doi: 10.11648/j.ijaas.20210702.14

Received: February 25, 2021; Accepted: March 12, 2021; Published: March 22, 2021

\begin{abstract}
The purpose of the research is to evaluate different varieties of alfalfa according to a complex of economically valuable characteristics. The study was carried out in the conditions of a foothill zone of the Central Caucasus in the fields SKNIIGPSH VNC RAN. The object of the study is 8 varieties of alfalfa Sarga (control), Manycheskaya, Kizlyarskaya, Sinegibridnaya, Vega 87, Lada, Nakhodka, Mira. The tab of experiments, observations and records were carried out according to generally accepted methods. Results and practical significance. The article presents a comparative characteristic of four varieties of alfalfa according to the main economically valuable characteristics and seed productivity. As a result of the research, it was found that in terms of the yield of green mass and leafiness, the varieties of alfalfa Sinegibridnaya and Kizlyarskaya surpassed other varieties by $5-7 \%$. High seed productivity among the tested varieties of alfalfa was possessed by the variety - Kizlyarsky. The Kizlyarsky variety combines high yield indicators of green mass, dry matter and weight of 1000 seeds. Scientific novelty. Improvement of existing and creation of new varieties of alfalfa with high seed productivity for the conditions of the foothill zone of the Central Caucasus. Methods. Records and observations were carried out according to the method of VIR and the V. R. Williams Feed Research Institute.
\end{abstract}

Keywords: Alfalfa, Seed Productivity, Variety, Ecological Plasticity

\section{Statement of the Problem (Introduction)}

Alfalfa belongs to the legume family and has the inherent ability to accumulate more or less nutritious nitrogenous substances due to the vital activity of nodule bacteria that settle on its roots. It is a high-yielding and high-protein forage crop. Its inherent high plasticity will allow it to adapt to various conditions of existence, so it is distributed almost everywhere $[4,6,13,14,16]$.

Alfalfa increases the fertility of the soil as a result of the accumulation of nitrogen in it. The accumulation of organic matter is of great importance in improving the physical and chemical properties of the soil. Alfalfa contains a lot of lysine, and in terms of the content of essential amino acids, it surpasses corn, sorghum, soy, barley and a number of other crops $[2,3,7,10,12,17]$.

In the roots, stems and leaves of alfalfa contains about 2 times more protein substances than in cereals, in its green mass more than $20 \%$ protein, in hay- $15-18 \%$ absolute dry matter. Alfalfa is rich in protein, micro-and macronutrients. Of the mineral salts, it contains a lot of calcium $(1.49 \%)$, phosphorus $(0.24 \%)$ and sulfur $(0.18 \%)$.

In recent years, in the Republic of RSO-Alania, the area of alfalfa crops is expanding, the demand for seeds is increasing, but their production remains at a low level. This is due to the lack of adaptive, highly productive varieties of alfalfa that are resistant to diseases, lodging and insufficient knowledge of a number of issues of its cultivation technology for seeds $[5,8$, $9,11,15,18,19]$.

\section{Research Methodology and Methods}

The purpose of the research is to evaluate the economically valuable characteristics of various varieties of alfalfa in the conditions of the foothill zone of the Central Caucasus. alfalfa plants that are resistant to biotic and abiotic 
environmental stress factors for cultivation in the North Caucasus on the basis of targeted selection of promising genotypes.

The research was conducted in the experimental field SKYISH VNC RAS. The study of breeding samples is carried out according to the method of the Higher Research Institute of Feed on the basis of high seed productivity, the speed of regrowth after mowing, disease resistance, leafiness and quality of the feed mass.

In the nursery, the following observations and records of each sample were carried out.

1. phenological observations by the method of ocular evaluation. The beginning of the phase is the period when $10-15 \%$ of the plants entered it. If $70-75 \%$ of the plants have entered it, the phase is considered complete.

2. the height of the herbage and the length of the generative shoots according to the phases of plant development.

3. leafiness - the ratio of the mass of leaves to the total weight of the aboveground mass.

The soil of alfalfa breeding nurseries is represented by leached chernozem, underlain by pebble deposits. According to $\mathrm{K}$. Kh. Byasov [1], the reaction of the soil solution ( $\mathrm{pH}$ is saline) and is close to neutral. These soils, as a rule, do not require liming. The humus content in the upper layer of the soil ranges from 5.88 to $7.42 \%$, its fall down the soil profile is gradual. The study of alfalfa samples was carried out according to the VIR method and the Feed Research Institute.

The objects of research were 8 varieties of alfalfa: Manycheskaya, Sarga, Kizlyarskaya, Sinegibridnaya, Vega 87, Lada, Nakhodka, Mira.

In the nursery, the plants were arranged in a wide row, discharged, for access and selection of each sample. The area of each nursery was 25-35 $\mathrm{m} 2$, where a comprehensive assessment was given to all the studied varieties of alfalfa. When sowing alfalfa, the square - nest method of forming new varieties of alfalfa was used. The leafiness of plants was determined in the flowering phase, according to the methodological guidelines of the selection of perennial grasses of the V. R. Williams Research Institute of Feed.

In the Kizlyarsky variety, the plant height reached $89.1 \mathrm{~cm}$ on average over three years, while others were lower, respectively, Manycheskaya by $17 \%(76.1 \mathrm{~cm})$, Sarga (control) by $27.2 \%(70.0 \mathrm{~cm})$ and Sinegibridnaya by $4.0 \%$ $(85.6 \mathrm{~cm})$ Vega by $29.3 \%(68.9 \mathrm{~cm})$, Lada by $27.6 \%(69.8$ $\mathrm{cm})$, Nakhodka by $19.2 \%(74.7 \mathrm{~cm})$, Mira by $18.8 \%(75.0$ $\mathrm{cm})$. On average over three years, the number of stems per 1 $\mathrm{m} 2$ was allocated a grade of Kizlyar and Seneviratna 110-120 $\mathrm{m} 2$. Also, on average for three years, the number of internodes of the Kizlyar and Sinegibridnaya varieties amounted to 18 pieces, and the control Sarga was 14 pieces, respectively.

Table 1. Phenological observations of the growth and development of the studied alfalfa varieties (2017-2019).

\begin{tabular}{|c|c|c|c|c|c|c|}
\hline The name of the variety & Branc-hing & Budding & Mass flowering & Height Plants', cm & Quantity stems per $1 \mathrm{~m}^{2}$ & Number of internodes \\
\hline Sarga control & 30.06 & 15.07 & 27.07 & 70.0 & 102.2 & 14 \\
\hline Manychskaya & 30.06 & 15.07 & 27.07 & 76.1 & 104.1 & 16 \\
\hline Kizlyar & 25.06 & 10.07 & 25.07 & 89.1 & 120.3 & 18 \\
\hline Sinegibridnaya & 30.06 & 10.07 & 25.07 & 85.6 & 110.1 & 18 \\
\hline Vega 87 & 30.06 & 15.07 & 27.07 & 68.9 & 104.3 & 13 \\
\hline Lada & 30.06 & 15.07 & 27.07 & 69.8 & 106.5 & 14 \\
\hline Nahodka & 28.06 & 12.07 & 25.07 & 74.7 & 102.8 & 12 \\
\hline
\end{tabular}

Another important indicator of alfalfa breeding samples is seed productivity, which mainly depends on the number of brushes with beans and the number of seeds in it, as shown in Table 2. The presence of a large number of vegetative stems on alfalfa crops during seed filling has a negative impact on the formation of generative organs, since the nutrients necessary for the formation of seeds are more spent on building up the vegetative mass.

Not only does the total number of generative stems per unit area of sowing have a certain value, but also per 1 plant.

Table 2. Formation of brushes on the same generative stem in different varieties of alfalfa (2017-2019).

\begin{tabular}{llll}
\hline \multirow{2}{*}{ Variety } & Number of generative stems per & The number on the stem 1 (PC.) \\
\cline { 2 - 4 } & plant, (PCs.) & brushes with beans \\
\hline Sarga control & 7.3 & 8.1 & brushes without beans \\
Manychskaya & 7.4 & 8.0 & 13.2 \\
Kizlyar & 8.7 & 9.2 & 13.1 \\
Sinegibridnaya & 8.2 & 8.8 & 9.4 \\
Vega 87 & 7.2 & 8.1 & 10.7 \\
Lada & 7.3 & 8.4 & 13.0 \\
Nahodka & 7.4 & 8.5 & 13.3 \\
Mira & 7.4 & 8.3 \\
\hline
\end{tabular}

According to this indicator, the varieties Kizlyarskaya and Sinegibridnaya distinguished themselves, in which the number of generative stems was: $8.2 ; 8.7$ pcs. accordingly. (Table 2 )

Leafiness is one of the most important indicators of the nutritional value of the variety. The leafiness of plants was determined in the flowering phase, according to the methodological guidelines of the selection of perennial grasses of the V. R. Williams Research Institute of Feed (Table 3). 
Table 3. Evaluation of promising varieties-samples of alfalfa by biological and economic characteristics.

\begin{tabular}{|c|c|c|c|c|c|c|c|}
\hline \multirow{2}{*}{$\begin{array}{l}\text { Variety and } \\
\text { selection lines }\end{array}$} & \multirow{2}{*}{$\begin{array}{l}\text { The } \\
\text { foliage, \% }\end{array}$} & \multicolumn{3}{|l|}{ Yield } & \multirow{2}{*}{$\begin{array}{l}\text { The shape of the } \\
\text { Bush }\end{array}$} & \multirow{2}{*}{$\begin{array}{l}\text { Protein } \\
\text { content in \% }\end{array}$} & \multirow{2}{*}{$\begin{array}{l}\text { Weight } 1000 \\
\text { seeds, g }\end{array}$} \\
\hline & & Green mass, $\mathrm{kg} / \mathrm{m}^{2}$ & Dry matter, $\mathrm{kg} / \mathrm{m}^{2}$ & Seeds $\mathrm{g} / \mathrm{m}^{2}$ & & & \\
\hline Sarga control & 49 & 1.47 & 0.31 & 9.1 & Semi-developed & 15.7 & 1.1 \\
\hline Manychskaya & 50 & 1.35 & 0.31 & 9.9 & Straight-standing & 17.1 & 1.6 \\
\hline Kizlyar & 57 & 1.53 & 0.32 & 11.4 & Straight-standing & 18.3 & 1.7 \\
\hline Sinegibridnaya & 55 & 1.52 & 0.33 & 10.8 & Straight-standing & 17.9 & 1.7 \\
\hline Vega 87 & 49 & 1.35 & 0.3 & 9.2 & Straight-standing & 15.0 & 1.2 \\
\hline Lada & 50 & 1.4 & 0.31 & 9.5 & Straight-standing & 15.2 & 1.3 \\
\hline Nahodka & 52 & 1.45 & 0.3 & 9.3 & Straight-standing & 15.3 & 1.4 \\
\hline Mira & 51 & 1.4 & 0.31 & 9.8 & Straight-standing & 15.2 & 1.2 \\
\hline
\end{tabular}

Of the 8 varieties of alfalfa studied in the conditions of North Ossetia in the nursery, was allocated two rooms that are most promising for breeding alfalfa with the best performance foliage and increased seed productivity in foothill zones.

In all cultivars, except for the Sarga variety, the bush is erect, the bushiness is average, the leafiness is $49-50 \%$. According to this indicator, the promising breeding samples Kizlyarskaya and Sinegibridnaya were distinguished, in which the leafiness of plants reaches $55-57 \%$. In terms of the yield of green mass, the Kizlyarskaya variety surpassed, with a yield of $1.53 \mathrm{~kg} / \mathrm{m} 2$, in other varieties the indicator varied from 1.35 to $1.5 \mathrm{~kg} / \mathrm{m} 2$. The shape of the bush in the studied cultivars is mostly erect, $30 \%$ of the plants were semi-developed.

The erect shape of the bush is convenient for mechanized harvesting of seed crops. The crude protein content is quite high (15.7-18.3\%), which makes it possible to produce food with high nutritional value.

\section{Discussion and Conclusions}

Our studies have shown that the growth of seed productivity was distinguished by the variety of alfalfa Kizlyarsky, which surpassed the other varieties in the yield of seeds, the formation of beans with a large number of seeds by $7-9 \%$. The yield of green mass and foliage varieties Seneviratna and Kizlyar higher than other varieties of 5-7\%, therefore, in the future will be used to develop new varieties. The highest productivity in the conditions of the foothill zone is possessed by the Kizlyarskaya variety, which most successfully combined the yield indicators of green mass, dry matter and weight of 1000 pcs. seeds.

\section{References}

[1] Byasov K. Kh. Natural resources of the Republic of North Ossetia-Alania. 2000.

[2] Bekuzarova S. A., Trifonova M. F., Ktsoeva M. S., Lushchenko G. V. Reduction of legume hard-seeding // Proceedings of the International Academy of agricultural education. 2018. No. 40. Pp. 137-139.

[3] Bekuzarova S. A., Ktsoeva M. S., Gagieva Z. V. Technology of cultivation of meadow clover for seeds/ / in the collection: Prospects for the development of agriculture in modern conditions Materials of the 8th International scientific and practical conference. 2019. Pp. 21-22.

[4] Gasiev V. And the Formation of agrocenoses of annual forage crops// Trends in the development of science and education. 2019. No. 46-5. Pp. 24-26.

[5] Gasiev V. I. Comparative assessment of productive crops of perennial grasses in the foothill zone of the RSO-Alania// Scientific life. 2018. No. 12. Pp. 58-62.

[6] Datieva I. A., Kelekhsashvili L. M., Farnieva K. Kh, doguzova N. N., Gazdanova I. O., Bekuzarova S. A. Selection of clover species for immunity in the conditions of RSO-Alania// Agrarian science. 2019. No. 5. Pp. 49-52.

[7] Matetskaya S. E., Doev G. Dz., Gappoev H. A. Economic efficiency of activation of symbiotic activity of alfalfa crops, energy assessment of alfalfa cultivation techniques//In the collection: Actual problems in modern science and ways to solve them Collection of articles based on the materials of the International scientific and practical conference. Under the editorship of O. N. Didmanidze. 2017. Pp. 46-52.

[8] Piskovatsky Yu. M., Lomova M. G. Selection of alfalfa varieties of pasture type. // Adaptive feed production. 2012. no. 2. Pp. 45-53.

[9] Salatova D. A., Arslanov M. A., Hasanov G. N. The rate of sowing alfalfa seeds in the crop period with various methods of pre-sowing soil treatment/ / agrarian science. 2018. no. 3. Pp. 54-56.

[10] Solozhentseva L. F., Piskovatsky Yu. M. Study of perspective material of alfalfa variable in terms of resistance to major diseases, productivity and quality // Adaptive feed production. 2018. no. 1. Pp. 26-34.

[11] Ranger Ch. M., Hower A. A. Glandular trichomes on perennial alfalfa affect host-selection behavior of empoasca fabae. / / Entomologia Experimentalis et Applicata. 2002. Vol. 105. No. 2-3. Pp. 71-81.

[12] Djilianov D., Prinsen E., Oden S., Van Onckelen H., Muller J. Nodulation under salt stress of alfalfa lines obtained after in vitro selection for osmotic tolerance. / / Plant Science. 2003. Vol. 165. No. 4. Pp. 887-894.

[13] Lamb J. F. S., Samac D. A., Barnes D. K., Henjum K. I. Increased herbage yield in alfalfa associated with selection for fibrous and lateral roots. // Crop Science. 2000. Vol. 40. No. 3. Pp. 693-699.

[14] Qi Yu, Huang Vongmei, Wang Yan, Zhao Jie, Zhang Jinghui. Biomass and its distribution in four species of meadow plants at different nitrogen levels / / Shengtai Xiebao=Acta ecol. Sin., 2011, 31, № 18, 5121-5129. kit. 
[15] Sarunaite Lina, Kadziuliene Zydre, Kadziulis Leonas. Zolynu derliaus formavimosi ir azoto kaupimosi sparta per pirmuosius dvejus ju auginimo metus / / Zemdirbyste, 2008. 95, No. 1. - P. 125-137.

[16] Ren Jingjing, LiJun, Wang Xu chang, Feng Xinyu. Characteristics of soil moisture and nutrients under alfalfa in semi-arid areas in the South of Ningxia province during drought / / Shengtai xuebao=Acta ecol. Sin. 2011. 31, No. 13, P. 3638-3649. kit.

[17] Potts S. C., Wodcock B. A., Roberts S. P., Tscheulin T. M., Pilgrim E. S., Brown V. K., Tallowin J. R. Enhancing pollinator biodiversity in intensive grasslands // J. Appl. Ecol. 2009. 46, № 2. - P. 369-379.
[18] Pang Jiayin, Tibbet Mark, Dentol Matthew, Lambers Hans. Variation in sowing growth of 11 perennial legumes in response to phosphorus supply / / Plant and Soil. 2010. 328, № 1-2, P. 133-143. Yield and water - use efficiency of contrasting Lucerne genotypes grown in a cool temperate environment / / Grop and Pastyre. Sci. 2011.62, № 7. - P. 610623.

[19] Montemayor Trejo Jose Alfredo, Woo Reza Jose Luis, Munguia Lopez Juan, Lopes Abdel Roman, Segura Castruita Miguel Angel, Yecas Coronado Pablo, Frias Ramires Ernesto. Production of alfaalfa (Medicago Sativa L.) cultivated with sub-Super irrigation / / Rev. mex. cienc. agr. - 2012.3, № 7. P. 1321-132. 